\title{
Biochemical and hormonal profile of the amniotic fluid from Nelore calves conceived by different reproduction biotechnologies
}

\author{
Perfil bioquímico e hormonal do líquido amniótico de bezerros \\ Nelore concebidos por diferentes biotecnologias
}

Marcelo Piagentini[ ${ }^{[a]}$, Nereu Carlos Prestes ${ }^{[b]}$, Carla Fredrichsen Moya-Araujo[c], Gustavo Henrique Marques Araujo[d], Regina Kiomi Takahira[e], Eunice Oba $a^{[[]}$

[a] Veterinarian, Phd in Animal Reproduction, Department of Animal Reproduction and Veterinary Radiology, School of Veterinary Medicine and Animal Science (FMVZ) (Unesp), Botucatu, SP - Brazil, e-mail: marcelovete@terra.com.br

[b] Veterinarian, Phd in Animal Reproduction, Department of Animal Reproduction and Veterinary Radiology, professor at the School of Veterinary Medicine and Animal Science (FMVZ) (Unesp), Botucatu, SP - Brazil,

e-mail: nereu@fmvz.unesp.br

[c] Veterinarian, Phd in Animal Reproduction, professor at the Faculdades Integradas of Ourinhos, Ourinhos, SP - Brazil, e-mail: carlafredrichsen@yahoo.com.br

[d] Veterinarian, Phd in Animal Reproduction, professor at the Unicastelo, Descalvado, SP - Brazil, e-mail:ghmaraujo@uol.com.br

[e] Veterinarian, Phd in Clinical Medicine, professor at the School of Veterinary Medicine and Animal Science (FMVZ) (Unesp), Botucatu, SP - Brazil, e-mail: takahira@fmvz.unesp.br

[f] Veterinarian, Phd in Animal Reproduction, Department of Animal Reproduction and Veterinary Radiology, professor at the School of Veterinary Medicine and Animal Science (FMVZ) (Unesp), Botucatu, SP - Brazil, e-mail:euniceoba@fmvz.unesp.br

\begin{abstract}
This study aimed to quantify biochemical constituents and hormonal concentrations in the amniotic fluid of Nelore calves conceived by different reproduction biotechnologies. Sixty animals were used and divided into: 1 - Twenty Nelore cows pregnant of calves obtained by artificial insemination; 2 - Twenty cows pregnant with Nelore calves obtained by embryo transference; 3 - Twenty cows pregnant with Nelore calves obtained by in vitro production. During the expulsion phase, the amnion was punctured and $15 \mathrm{~mL}$ of fluid were collected. The biochemical evaluation was performed with commercial kits in accordance to the manufacturer's recommendations. It was used the radioimmunoassay to assess the progesterone and testosterone levels. The statistical analysis used was the variance analysis and Tukey ( $5 \%$ significance level). Mean urea and creatinine when comparing the three groups showed that group 3 had higher values of these two metabolites, suggesting that the kidney maturity is suitable. For gamma-glutamyltransferase, group 3 had a lower value compared to group 1 . This enzyme is related to metabolism, may be inferred that the metabolic activity is high in animal production in vitro. The glucose values did not differ between the groups, suggests that the maternal-fetal exchanges were suitable for the power supply to the fetus. Lower chloride concentration was showed in group 3. Sodium and potassium were found in greater quantities in group 3 when compared to other groups. There was no significant difference for the testosterone
\end{abstract}


and progesterone. The results obtained in biochemical analysis can conclude that the renal and liver activity and maternal-fetal exchange are normal in the different groups.

Keywords: Amniotic fluid. Laboratorial analyses. Nelore.

\section{Resumo}

O presente trabalho teve por objetivo quantificar a concentração dos constituintes bioquímicos e hormonal no líquido amniótico de fetos Nelore, oriundos de diferentes biotécnicas reprodutivas. Utilizaram-se 60 vacas gestantes divididas em: 1 - 20 vacas prenhes de bezerros oriundos de inseminação artificial convencional (IA); 2 - 20 vacas prenhes de bezerros oriundos de transferência de embriões (TE) e 3 - 20 vacas prenhes de bezerros oriundos de produção in vitro (PIV). Durante a fase de expulsão, o âmnion foi puncionado e colheram-se $15 \mathrm{~mL}$ de líquido amniótico. As determinações bioquímicas foram conduzidas por kits comerciais. A progesterona e a testosterona foram determinadas por meio de radioimunoensaio (RIA) em fase sólida. Empregou-se a análise de variância e teste de Tukey com 5\% de significância. $O$ teor de ureia e creatinina no G3 foi maior que nos outros grupos e significativo $(p<0,05)$ em relação ao G1. Para gamaglutamiltransferase (GGT), o G3 apresentou menor valor em relação ao G1 $(p<0,05)$. Os valores de glicose não diferiram entre os grupos. O cloreto apresentou maior concentração em G1 e G2 que no G3 $(p<0,05)$. O sódio e o potássio foram encontrados em maior quantidade no $G 3$ em relação aos demais grupos. Na análise hormonal não foi detectada diferença significativa para testosterona e progesterona. Pelos teores de ureia e creatinina, concluiu-se que a presença destes, sugere maturidade renal adequada, que a GGT (relacionada ao metabolismo animal) está elevada nos bezerros de produção in vitro e que os grupos tiveram a concentração de glicose adequada ao fornecimento de energia ao feto. Os resultados obtidos na análise bioquímica indicam que a atividade renal e hepática, além das trocas materno-fetal, está normal nos diferentes grupos.

Palavras-chave: Líquido amniótico. Análise laboratorial. Nelore.

\section{Introduction}

The amniotic fluid is an important indicator of fetal health and its contents are factors that can help to clarify gestational problems. This fluid can be submitted to a variety of tests including biochemistry, cytology, biophysics and immunology assays. These evaluations can determine the maturity of fetal pulmonary, renal, and epidermal systems. In addition, they can detect genetic abnormalities and other disorders (KJELDSBERG; KNIGHT, 1993).

The fluid allows the fetus to adopt an adequate position prior to parturition, providing protection against traumas, dehydration and temperature variations. It also enables the fetus to grow and move without causing any harm to the uterus. Not only that, but the fluid promotes cervix, vagina and vulva dilatation during parturition, lubricating the vagina after the chorioallantois disruption helping the calf to pass through the vaginal canal. Apart from having bactericidal proprieties, these fluids also avoid skin adhesions (PRESTES; LANDIMALVARENGA, 2006 ; TONIOLLO; VICENTE, 1995).

The fetal fluids components and their relation to both the concept viability and maturity have been studied in different species, but in the bovine species there are only a few recent reports of the biochemical and hormonal profile of these fluids. Hence, the purpose of the present study was to quantify biochemical constituents, progesterone and testosterone concentration at amniotic fluid at the delivery time of Nelore calves that were conceived by either in vitro production (IVP), conventional embryo transfer (ET) or artificial insemination (AI), and compare them.

\section{Materials and methods}

The laboratory part of the study was performed at theDepartmentofAnimalReproductionand Veterinary Radiology in collaboration with the Department 
of Clinical Veterinary Medicines at the School of Veterinary Medicine and Animal Science (FMVZ), Botucatu, São Paulo, Brazil (22 $\left.{ }^{\circ} 51^{\prime} \mathrm{S} / 48^{\circ} 26^{\prime} \mathrm{W}\right)$.

Sixty animals were kindly offered by private farms that were located in the rural area of Avaré, São Paulo, Brazil ( $\left.23^{\circ} 03^{\prime} \mathrm{S} / 48^{\circ} 55^{\prime} \mathrm{W}\right)$ in order to perform the sample collection of amniotic fluid. Herd health assessment and vaccination program were performed according to the farms' management schedule. All animals were kept on pasture and supplemented with silage, industrial feed and water ad libitum. The cows were divided into three groups: 1-Twenty Nelore pregnant cows with calves obtained by AI; 2-Twenty pregnant cows of ET with Nelore calves obtained by superovulation of embryo donors and 3-Twenty pregnant cows with Nelore calves obtained by IVP after follicular aspiration.

Close to the expected calving date the cows were transferred to a calving paddock to facilitate labor observation. During the expulsion phase of the labor, the amnion was punctured and $15 \mathrm{~mL}$ of fluid were collected using a $40 \times 12 \mathrm{G}$ needle and a $20 \mathrm{~mL}$ syringe. The material was deposited in plastic $50 \mathrm{~mL}$ tubes and frozen in regular freezer $\left(-20^{\circ} \mathrm{C}\right)$ for later analysis. Biochemical analyses of the amniotic fluid samples were performed at the Clinic Laboratory of the Department of Clinical Veterinary Medicine - FMVZ, Botucatu, São Paulo, Brazil. The hormonal assays were performed at the Endocrinology Laboratory of the Animal Reproduction and Veterinary Radiology of the same School.

It was used commercial kits according to the manufacturer recommendation in order to evaluate the biochemical parameters as follows: Glucose - (mg/dL) colorimetric method (glucose SL; Celm ${ }^{\circledR}$; Barueri, SP) spectrophotometer Celm SB-190; Urea - (mg/dL) colorimetric method (urea ES; Celm ${ }^{\circledR}$; Barueri, SP) spectrophotometer Celm SB-190; Creatinine-(mg/dL) kinetic method (kinetic creatinine; Celm ${ }^{\circledR}$; Barueri, N= SP) - spectrophotometer Celm SB-190; Gamma-glutamyltransferase (GGT) - (UI/L) kinetic method (gamma GT; Celm ${ }^{\circledR}$; Barueri-SP) spectrophotometer Celm E-210S; Sodium - (mmol/L) flame photometry (sodium; Celm $^{\circledR}$; Barueri, SP) flame photometer Celm FC-280; Potassium - (mmol/L) flame photometry (potassium; Celm ${ }^{\circledR}$; Barueri, SP) flame photometer Celm FC-280; Chloride - (mmol/L) colorimetric method (chlorides; Labtest ${ }^{\circledR}$; Lagoa Santa, MG) spectrophotometer Celm SB-190; Total Protein (g/dL) colorimetric method (total proteins; Labtest ${ }^{\circledR}$; Lagoa Santa, MG) - spectrophotometer Celm SB-190. Progesterone and testosterone concentrations in the amniotic fluid were determined by radioimmunoassay (RIA) using commercial kits in solid phase (Diagnostic Products Corporation DPC; MedLab ${ }^{\circledR}$; São Paulo, SP). Results were analyzed with Gama Count Cobra II and it was used the variance analysis and Tukey test ( $5 \%$ of significance level) for the statistical study.

\section{Results}

Mean values and standard deviation for the biochemical parameters of the amniotic fluid, of the fetuses conceived by AI, ET or IVP are described in the Table 1.

It was observed that group 1 presented lower urea mean value when compared to groups 2 and 3 . As for both creatinine and sodium, group 3 had higher levels than group $1(\mathrm{p}<0.05)$, and group 2 presented intermediated levels of such substances, and similar values when compared to other groups' values $(p>0.05)$. Glucose and total protein levels did not differ among groups. For group 1, GGT levels were statically higher than for group 3, and group 2 showed intermediated levels, which were similar to the other both groups. Chloride levels were higher for group $3(\mathrm{p}<0.05)$ and potassium levels were higher for group $2(p<0.05)$.

Table 2 shows mean and standard error of the progesterone and testosterone for all groups. The hormone concentration analysis disregarded the fetal gender. The results did not show any relevant statistical difference among groups ( $p>0.05$ ).

Table 1 - The mean values and standard deviation for the biochemical parameters obtained from the amniotic fluid at calving in the different groups

(CONTINUE)

\begin{tabular}{lccc}
\hline & \multicolumn{3}{c}{ Groups } \\
\cline { 2 - 4 } Parameters & $\mathbf{1}(\mathrm{Al})$ & $\mathbf{2}$ (ET) & $\mathbf{3}$ (IVP) \\
\cline { 2 - 4 } & $28.1 \pm 17.1^{\mathrm{b}}$ & $38.3 \pm 20.5^{\mathrm{a}}$ & $40.3 \pm 16.5^{\mathrm{a}}$ \\
\hline Urea $(\mathrm{mg} / \mathrm{dL})$ & $5.2 \pm 4.6^{\mathrm{b}}$ & $5.9 \pm 4.9^{\mathrm{ab}}$ & $8.0 \pm 5.3^{\mathrm{a}}$ \\
Creatinine $(\mathrm{mg} / \mathrm{dL})$ & $6.7 \pm 7.7$ & $4.4 \pm 6.1$ \\
Glucose $(\mathrm{mg} / \mathrm{dL})$ & $4.4 \pm 7.1$ & \multicolumn{3}{c}{${ }^{3}$}
\end{tabular}


Table 1 - The mean values and standard deviation for the biochemical parameters obtained from the amniotic fluid at calving in the different groups

(CONCLUSION)

\begin{tabular}{lccc}
\hline \multirow{3}{*}{ Parameters } & \multicolumn{3}{c}{ Groups } \\
\cline { 2 - 4 } & $\mathbf{1}(\mathrm{AI})$ & $\mathbf{2}$ (ET) & $\mathbf{3}$ (IVP) \\
\hline Total protein (g/dL) & $0.27 \pm 0.29$ & $0.36 \pm 0.57$ & $0.45 \pm 0.46$ \\
GGT (UI/L) & $35.0 \pm 42.9^{\mathrm{a}}$ & $22.6 \pm 13.0^{\mathrm{ab}}$ & $17.2 \pm 14.6^{\mathrm{b}}$ \\
Chloride (mmol/L) & $101.1 \pm 43.5^{\mathrm{a}}$ & $88.8 \pm 23.8^{\mathrm{a}}$ & $63.7 \pm 31.5^{\mathrm{b}}$ \\
Sodium (mmol/L) & $74.4 \pm 33.9^{\mathrm{b}}$ & $77.7 \pm 33.4^{\mathrm{ab}}$ & $94.8 \pm 33.6^{\mathrm{a}}$ \\
Potassium & $5.9 \pm 8.1^{\mathrm{ab}}$ & $3.9 \pm 1.8^{\mathrm{b}}$ & $8.3 \pm 7.1^{\mathrm{a}}$ \\
(mmol/L) & & & \\
\hline
\end{tabular}

Source: Research data.

Note: ${ }^{a, b}=$ Values within rows with different superscripts are significantly different $(p<0.05)$.

Table 2 - The mean values and standard deviation for the hormonal concentration obtained from the amniotic fluid at calving in the different groups.

\begin{tabular}{lccc}
\hline \multirow{4}{*}{ Parameters } & \multicolumn{3}{c}{ Group } \\
\cline { 2 - 4 } & $\mathbf{0 1}$ (Al) & $\mathbf{0 2 ~ ( E T ) ~}$ & $\mathbf{0 3 ~ ( I V P ) ~}$ \\
\hline Progesterone (ng/mL) & $7.9 \pm 6.1$ & $8.1 \pm 6.3$ & $6.1 \pm 5.4$ \\
Testosterone (ng/dL) & $7.8 \pm 6.6$ & $8.7 \pm 11.4$ & $5.1 \pm 4.6$ \\
\hline
\end{tabular}

Source: Research data.

Note: $(p>0.05)$.

\section{Discussion}

Creatinine is one of the most studied biochemical compound and its level can be used to determine the fetal kidney maturation during gestation. It can be detected in the fluid due to the gradient difference among the umbilical cord, digestory mucosa and bronchial mucosa, by simple diffusion. Creatinine is a non protein nitrogen substance excreted via glomerullar filtration, as the kidney gets more mature it excretes higher concentrations of creatinine, increasing its levels in the amniotic fluid. The urea concentration level is used to evaluate the kidney maturation at veterinary and human medicine, in parallel to the creatinine level (HERVEY; SLATER, 1967; VOTTA, 1975). Creatinine mean concentration observed in groups 1 and 2 was lower than the one found in the bovine species (BAETZ et al., 1976), but for group 3 mean concentration values were similar. Urea concentration values for group 1 were similar to the ones found for the bovine (BAETZ et al., 1976) and ovine (PRESTES et al., 2001) species. These creatinine and urea concentration values suggested satisfactory kidney maturation.

Glucose is the main sugar at the fetuses' blood; therefore it is the main energy source. Large amount of the produced glucose is obtained via facilitated transport across the maternal and the fetal placenta. The mean concentration values of glucose in the three groups were higher than the ones found in the ovine species (PRESTES et al., 2001). The finding of no statistical difference in the results indicates that the maternal-fetal glucose transport were at normal levels.

The GGT is an enzyme found in high concentration in the kidney, liver and pancreas, acting at metabolic level mediating a large number of physiological functions. In relation to the mean concentration of GGT, this experiment had shown that the three groups had a higher level of this enzyme than the one reported in ovine species (PRESTES et al., 2001).

Potassium and sodium urine excretion are regulated by aldosterone that is produced on the fetal adrenal gland, and the main results are the increase in the potassium and decrease in the sodium concentrations, and this is sufficient to indicate the fetal kidney maturity. The amniotic fluid's sodium and chloride concentrations depend on the oronasal secretions during gestation (EVRARD et al., 1997). The mean sodium concentration in the amniotic fluid in the three groups was lower than other results found in the reviewed literature (BRACE et al., 2004; GAGNON et al., 2002; PRESTES et al., 2001) for the ovine species. The potassium concentration in group 1 was similar to the one described in the ovine species by Brace etal. (2004), but its value was lower in group 2 and its value was higher in group 3. However, other authors described a higher potassium level than three groups (PRESTES et al., 2001). Baetz et al. (1976), in the bovine species, described potassium concentration was similar in group 1 , but 
its value was lower in group 2 and its value was higher in group 3.

Brace et al. (2004) described an ovine chloride level similar to the one for animals in group 1 and higher than the results for group 2 and 3. However, other authors in the ovine species also (GAGNON et al., 2002) had shown a lower chloride concentration when compared to the findings from group 1 and a higher concentration when compared to groups 2 and 3, in contradiction to the results from Evrard et al. (1997), which showed a higher level of chloride.

The testosterone concentration level found for the three groups during this experiment was lower than the one described in another paper (MAIA et al., 2004). On the other hand the progesterone concentration level showed in this experiment was higher than the concentration reported by Maia et al. (2004). These results differed probably due to hormonal kit used.

\section{Conclusion}

The results obtained in biochemical analysis can conclude that the renal and liver activity and maternal-fetal exchange are normal in the different groups. The amniotic fluid is an important source for fetal evaluation through biochemical and hormonal analysis that allow the determining process of hepatic and renal maturity in the fetus.

\section{Acknowledgments:}

Research received financial support from Fapesp.
EVRARD, V. et al. Intra-uterine tracheal obstruction decreases amniotic fluid sodium and chloride concentration in the fetal lamb. American Journal of Obstetrics \& Gynecology, v. 176, n. 1, p. 171, 1997.

GAGNON, R.; HARDING, R.; BRACE, R.A. Amniotic fluid and fetal urinary responses to severe placental insufficiency in sheep. American Journal of Obstetrics \& Gynecology, v. 186, n. 5, p. 1076-1084, 2002.

HERVEY, E. J.; SLATER, J. S. The source of sheep fetal fluids in the later stages of gestation. The Journal of Physiology, v. 22, n. 1, p. 40-41, 1967.

KJELDSBERG, C.; KNIGHT, J. Body fluid: laboratory examination of amniotic, cerebroespin, serus and synovial fluids. In: American Society for Clinical Pathology. Chicago: Theid, 1993.

MAIA, M. et al. Concentração dos hormônios esteróides no plasma sanguíneo fetal e nos líquidos amniótico e alantoideano no terço inicial, médio e final da gestação de vacas. ARS Veterinária, v. 20, n. 3, p. 353-360, 2004.

PRESTES, N. C.; CHALHOUB, M. C. L.; LOPES, M. D. Amniocentesis and biochemical evaluation of amniotic fluid in ewes at 70, 100 and 145 days of pregnancy. Small Ruminant Research, v. 39, n. 3, p. 277-281, 2001

PRESTES, N. C; LANDIM-ALVARENGA, F. C. Medicina Veterinária - Obstetrícia Veterinária. Rio de Janeiro: Guanabara-Koogan, 2006.

TONIOLLO, G. H.; VICENTE, W. R. R. Manual de obstetrícia veterinária. São Paulo: Livraria Varela, 1995. 86p.

VOTTA, R. A. Aplicaciones clínicas del estudo de la creatinina del líquido amniótico. In: VOTTA, R. A. Investigaciones clínicas al conocimiento del estado fetal. México: Panamericana, 1975 p. 59-63.

\section{References}

BAETZ, A. L.; HUBERT, W. T.; GRAHAN, C. K. Changes of bioReceived: 07/19/2012 Recebido: 19/07/2012 chemical constituents in bovine fetal fluids with gestational age. American Journal of Veterinary Research, v. 37, n. 9, p. 1047-1052, 1976.

Approved: $10 / 23 / 2012$ Aprovado: 23/10/2012

BRACE, R. A.; VERMIN, L. M.; HUIJSSOON, E. Regulation of amniotic fluid volume: intramembranous solute and volume fluxes in late gestation fetal sheep. American Journal of Obstetrics \& Gynecology, v. 191, n. 3, p. 837-846, 2004. 